\title{
COMPARISON OF ANGIOSOME BASED INCISION WITH CONVENTIONAL AGGRESSIVE DEBRIDEMENT FOR THE TREATMENT OF DIABETIC FOOT ULCERS.
}

1. MBBS, FCPS (G. Surgery), FCPS (Urology)

Associate Professor Surgery Nishtar Medical University/ Hospital Multan

2. MBBS, FCPS (G. Surgery) Professor Anatomy Nishtar Medical University/ Multan

3. MBBS, FCPS (G. Surgery)

Assistant Professor Surgery Nishtar Medical University/ Hospital Multan.

4. MBBS, FCPS (G. Surgery) Professor Anatomy

Nishtar Medical University Multan.

5. MBBS, FCPS (Gynae \& Obs) Demonstrator Anatomy Nishtar Medical University Multan.

6. MBBS

PGR Surgical Unit

Nishtar Medical University/ Hospital Multan.

Correspondence Address:

Dr. Naveed Akhta

Department of Surgery

Nishtar Medical University/ Hospital

Multan.

drchnaveed@yahoo.com

Article received on:

03/12/2018

Accepted for publication: $12 / 10 / 2019$
Naveed Akhtar ${ }^{1}$, Muhammad llyas Anjum², Shafiq Ullah ${ }^{3}$, Shahid Mansoor Nizami ${ }^{4}$, Uzma Rasheed ${ }^{5}$, Anas Rabbani ${ }^{6}$

ABSTRACT... Objectives: To compare the efficacy of angiosome based incisions versus aggressive debridement for the treatment of diabetic foot ulcer. Study Design: Randomized Controlled Trial. Setting: Surgical Unit 1 Nishtar Medical University/ Hospital Multan. Period: 9 months duration, from $1^{\text {st }}$ January 2017 to $30^{\text {th }}$ September 2017. Material \& Methods: Sample Size: Total 210 patients, 105 in each group. Sampling Technique: Non-probability, consecutive sampling. 210 patients of both genders with history of diabetes mellitus having Grade II diabetic foot ulcer below the ankle. Before the procedure, foot ulcers were measured and ulcer dimensions equal or greater than $4 \mathrm{~cm}^{2}$ were included in the study. 105 patients were in angiosome based incision group (Group A), while105 patients were in aggressive debridement group (Group B). Patients were called for follow up after every 5 days. Regular dressings were done to allow more regular wound inspection and cleansing to avoid infection. Results: Age range in this study was from 30 to 60 years with mean age of $45.971 \pm 4.89$ years in Group A while $46.457 \pm 6.22$ years in Group B. Mean duration of diabetes was $10.171 \pm 4.09$ years in Group A and 10.561 \pm 5.58 years in Group B. Mean duration of foot ulcer was $3.895 \pm 2.72$ months in Group A and 3.790 \pm 2.03 months in Group B. Mean size of foot ulcer was $5.047 \pm 1.52$ $\mathrm{cm}^{2}$ in Group A and 4.895 $\pm 1.67 \mathrm{~cm}^{2}$ in Group B. Mean weight of the patients was $68.238 \pm 10.44$ $\mathrm{kg}$ in Group A and $67.742 \pm 9.53 \mathrm{Kg}$ in Group B. Majority of the patients were of $46-60$ years in group A (63.8\%) and in group B (66.7\%). Male gender was dominant in both group $(73.3 \%$ and 55.25). In group A efficacy was seen in 96 (91.4\%) patients as compare to 47 (44.8\%) patients in group $B,(P=0.000)$. Conclusion: Angiosome based incision in the treatment of diabetic foot ulcer has shown outstanding outcome with respect to wound healing compared with aggressive debridement.

Key words: $\quad$ Angiosome Based Incision, Aggressive Debridement, Diabetic Foot Ulcer.

Article Citation: Akhtar N, Anjum MI, Shafiq Ullah, Nizami SM, Rasheed U, Rabbani A. Comparison of angiosome based incision with conventional aggressive debridement for the treatment of diabetic foot ulcers. Professional Med J 2020; 27(6):1097-1102. DOI: 10.29309/TPMJ/2020.27.06.1838

\section{INTRODUCTION}

Diabetes mellitus (DM) is major health problem in our society. Globally it is increasing over the last 20 years. ${ }^{1,2,3}$ Diabetic patients are prone to develop many complications. Diabetic Foot Ulcer (DFU) is the most common complication of diabetes mellitus. ${ }^{4,5}$ Diabetic patients has 15\% chance to develop DFU during their lifetime. ${ }^{6,7}$

"Debridement means removal of the necrotic tissues, foreign bodies and infected materials from the wound". ${ }^{8}$ Debridement reduces pressure thus facilitates wound drainage and decreasing the bacterial load. $^{9}$ Debridement stimulates growth factors thus improves healing.
The angiosome principle, defined by lan Taylor in 1987, divides the body into three-dimensional anatomic units of tissue supplied by specific arteries. "An angiosome is an arterial supply to a defined area of tissues". The word angiosome is derived from Greek word angeon, meaning blood vessel and somatikos means the pertinence to the body. ${ }^{11,12}$ Incisions based on Angiosome facilitate wound healing and decrease amputations rates.

Taylor divides the leg in to 3 angiosomes, the angiosomes of anterior tibial, posterior tibial and peroneal arteries. ${ }^{12}$ Some tissues receive blood from branches of two angiosomes. 


\section{OBJECTIVE}

To compare the efficacy of angiosome based incisions versus aggressive debridement in treatment of diabetic foot ulcer patients.

Diabetic foot ulcer was defined as a wound of dimensions equal or greater than $4 \mathrm{~cm}^{2}$ on physical examination below the ankle with Grade II Ulcer.

The efficacy was defined as when ulcer heals on physical examination after 30 days.

\section{MARERIAL AND METIHODS}

It was a Randomized Controlled Trial, conducted at Surgical Unit 1 Nishtar Medical University/ Hospital Multan.

The Duration of Study was 9 months duration, from $1^{\text {st }}$ January 2018 to $30^{\text {th }}$ September 2018.

This is study were Total 210 patients, 105 in each groupthese were selected by Non-probability, consecutive sampling.

Inclusion Criteria

Age 30-60 years of both Genders having H/O Diabetes with Grade II Diabetic foot ulcer below the ankle and Ulcer dimensions equal or greater than $4 \mathrm{~cm}^{2}$ on physical examination.

\section{Exclusion Criteria}

Gangrene foot on physical examination, history of getting immunosuppressive therapies, Osteomyelitis and renal disease.

Patients fulfilling the inclusion criteria were admitted in surgical Unit I Nishtar hospital Multan. Study started after permission from ethical committee and research department of Nishtar Medical University/ Hospital Multan. A detailed explanation about the procedure was given to the patient and a written informed consent was obtained explaining the risks and benefits.

Before the procedure, foot ulcers were measured. A double layer of polyethylene sheets was held firmly in place over the wound, and an outline of the wound was traced using a permanent marker. The layer in direct contact with the wound was discarded. The tracing made on the top layer of polyethylene was fixed against a graphic paper and its area was measured.

In Group A, incisions were made according to angiosome model and in group $B$ aggressive debridement was done in routine manner. Debridement was performed on all wounds in the operating theatre under local Anesthesia. Prophylactic antibiotics were given. Debridement entailed the excision of all necrotic and infected tissue until healthy, bleeding tissue was reached. After debridement, the wound was thoroughly cleansed and irrigated by jet lavage, dressing was placed and patients were sent to home. Patients were called for follow up after every $6^{\text {th }}$ day to allow more regular wound inspection and cleansing to avoid infection.

Dressing was left in place for 2 days, and then change of dressing was done by a local doctor. Efficacy of treatment was finally determined after 30 days as per operational definition by measuring the ulcer dimension by similar procedure as done before the start of procedures. Data was noted on especially designed proforma.

Data was analyzed with statistical analysis program (SPSS version20). Frequency and percentage was computed for qualitative variables like gender and efficacy. Mean \pm SD was presented for quantitative variables like age, duration of diabetes, duration of foot ulcer, size of ulcer and weight of the patient. Chi-square test was applied to compare efficacy in both groups taken $p \leq 0.05$ as significant. Stratification was done with regard to age, gender, duration of diabetes, duration of foot ulcer, size of ulcer and weight to see the effect of these on efficacy. Post stratification using the chi-square test for both groups, $p \leq 0.05$ was considered statistically significant.

\section{RESULTS}

Age range in our study was from 30 to 60 years with mean age of $45.971 \pm 4.89$ years in Group A while $46.457 \pm 6.22$ years in Group B. Mean duration of diabetes was $10.171 \pm 4.09$ years in 
Group A and $10.561 \pm 5.58$ years in Group B. Mean duration of foot ulcer was $3.895 \pm 2.72$ months in Group A and 3.790 \pm 2.03 months in Group B.

Mean size of foot ulcer was $5.047 \pm 1.52 \mathrm{~cm}^{2}$ in Group A and 4.895 $\pm 1.67 \mathrm{~cm}^{2}$ in Group B. Mean weight was $68.238 \pm 10.44 \mathrm{~kg}$ in Group $A$ and $67.742 \pm 9.53 \mathrm{Kg}$ in Group B as shown in Table-l.

\begin{tabular}{|c|c|c|c|}
\hline \multicolumn{2}{|c|}{ Demographics } & $\begin{array}{c}\text { Mean } \\
\text { Group A } \\
\text { n=105 }\end{array}$ & $\begin{array}{c}\text { Mean } \pm \text { SD } \\
\text { Group B } \\
\mathbf{n = 1 0 5}\end{array}$ \\
\hline $\mathbf{1}$ & Age(years) & $45.971 \pm 4.89$ & $46.457 \pm 6.22$ \\
\hline $\mathbf{2}$ & $\begin{array}{c}\text { Duration of } \\
\text { Diabetes (years) }\end{array}$ & $10.171 \pm 4.09$ & $10.561 \pm 5.58$ \\
\hline 4 & $\begin{array}{c}\text { Duration of Foot } \\
\text { Ulcer (months) }\end{array}$ & $3.895 \pm 2.72$ & $3.790 \pm 2.03$ \\
\hline 5 & $\begin{array}{c}\text { Size of Foot Ulcer } \\
\text { (cm }{ }^{2} \text { ) }\end{array}$ & $5.047 \pm 1.52$ & $4.895 \pm 1.67$ \\
\hline 5 & Weight (Kg) & $68.238 \pm 10.44$ & $67.742 \pm 9.53$ \\
\hline
\end{tabular}

Table-I. Mean \pm SD of patients according to age, duration of diabetes, duration of foot ulcer, size of foot ulcer and weight in both groups. $n=210$

Majority of the patients were of $46-60$ years in group A (63.8\%) and $66.7 \%$ were in group $B$. Male gender was dominant in both group (73.3\% in group $A$ and $55.25 \%$ in group $B$ ). In group A efficacy was seen in 96 (91.4\%) patients as compare to $47(44.8 \%)$ patients in group B, $(P=0.000)$ as shown in Table-II.

\begin{tabular}{|c|c|c|c|}
\hline \multirow{2}{*}{ Efficacy } & $n=105$ & $n=105$ & \multirow{2}{*}{ P-Value } \\
\hline & Group A & Group B & \\
\hline Yes & 96 (91.4\%) & 47 (44.8\%) & \multirow{3}{*}{0.000} \\
\hline No & $9(8.6 \%)$ & 58 (55.2\%) & \\
\hline Total & 105 (100\%) & 105 (100\%) & \\
\hline
\end{tabular}

Table-II. Comparison of efficacy in both groups $n=210$

Stratification of efficacy with regard to age, gender, duration of diabetes, duration of foot ulcer, size of foot ulcer and weight are shown in Table-III, IV, V, VI, VII and VIII respectively.

\begin{tabular}{|c|c|c|c|}
\hline \multicolumn{4}{|c|}{ For Age Group 30-45 Years } \\
\hline \multirow[b]{2}{*}{ Group } & \multicolumn{2}{|c|}{ Efficacy } & \multirow{2}{*}{ P-Value } \\
\hline & Yes & No & \\
\hline A & $33(86.8 \%)$ & $5(13.2 \%)$ & \multirow{2}{*}{0.000} \\
\hline B & $17(48.6 \%)$ & $18(51.4 \%)$ & \\
\hline \multicolumn{4}{|c|}{ For Age Group 46-60 Years } \\
\hline Group & Yes & No & \multirow{3}{*}{0.000} \\
\hline A & $63(94 \%)$ & $4(6 \%)$ & \\
\hline B & $30(42.9 \%)$ & $40(57.1 \%)$ & \\
\hline \multicolumn{4}{|c|}{$\begin{array}{l}\text { Table-III. Stratification of efficacy with respect to age } \\
\text { in Group A and Group B }\end{array}$} \\
\hline \multicolumn{4}{|c|}{ For Male } \\
\hline & \multicolumn{2}{|c|}{ Efficacy } & \multirow{2}{*}{ P-Value } \\
\hline Group & Yes & No & \\
\hline A & $69(89.6 \%)$ & $8(10.4 \%)$ & \multirow{2}{*}{0.000} \\
\hline B & $23(39.7 \%)$ & $35(60.3 \%)$ & \\
\hline \multicolumn{4}{|c|}{ For Female } \\
\hline Group & Yes & No & \multirow{3}{*}{0.000} \\
\hline A & $27(96.4 \%)$ & $1(3.6 \%)$ & \\
\hline B & $24(51.1 \%)$ & $23(48.9 \%)$ & \\
\hline \multicolumn{4}{|c|}{$\begin{array}{l}\text { Table-IV. Stratification of efficacy with respect to } \\
\text { gender in Group A and Group B }\end{array}$} \\
\hline \multicolumn{4}{|c|}{ Duration $\leq 10$ Years } \\
\hline & \multicolumn{2}{|c|}{ Efficacy } & \multirow{2}{*}{ P-Value } \\
\hline Group & Yes & No & \\
\hline A & $62(89.9 \%)$ & $7(10.1 \%)$ & \multirow{2}{*}{0.000} \\
\hline B & $23(35.9 \%)$ & $41(64.1 \%)$ & \\
\hline \multicolumn{4}{|c|}{ Duration > 10 Years } \\
\hline Group & Yes & No & \multirow{3}{*}{0.000} \\
\hline A & $34(94.4 \%)$ & $2(5.6 \%)$ & \\
\hline B & $24(58.5 \%)$ & $17(41.5 \%)$ & \\
\hline \multicolumn{4}{|c|}{$\begin{array}{l}\text { Table-V. Stratification of efficacy with respect to } \\
\text { duration of diabetes in Group A and Group B }\end{array}$} \\
\hline \multicolumn{4}{|c|}{ Duration 1-5 Months } \\
\hline & \multicolumn{2}{|c|}{ Efficacy } & \multirow{2}{*}{ P-Value } \\
\hline Group & Yes & No & \\
\hline A & $86(91.5 \%)$ & $8(8.5 \%)$ & \multirow{2}{*}{0.000} \\
\hline B & $39(42.4 \%)$ & $53(57.6 \%)$ & \\
\hline \multicolumn{4}{|c|}{ Duration > 5 Months } \\
\hline Group & Yes & No & \multirow{3}{*}{0.097} \\
\hline A & $10(90.9 \%)$ & $1(9.1 \%)$ & \\
\hline B & $8(61.5 \%)$ & $5(38.5 \%)$ & \\
\hline
\end{tabular}




\begin{tabular}{|c|c|c|c|}
\hline \multicolumn{4}{|c|}{ Size $4-6 \mathrm{~cm}^{2}$} \\
\hline & \multicolumn{2}{|c|}{ Efficacy } & \multirow{2}{*}{ P-Value } \\
\hline Group & Yes & No & \\
\hline A & $73(89 \%)$ & $9(11 \%)$ & \multirow{2}{*}{0.339} \\
\hline B & $33(39.3 \%)$ & $51(60.7 \%)$ & \\
\hline \multicolumn{4}{|c|}{ Size $>6 \mathrm{~cm}^{2}$} \\
\hline Group & Yes & No & \multirow{3}{*}{0.002} \\
\hline A & $23(100 \%)$ & $0(0 \%)$ & \\
\hline B & $14(66.7 \%)$ & $7(33.3 \%)$ & \\
\hline
\end{tabular}

Table-VII. Stratification of efficacy with respect to size of foot ulcer in Group A and Group B

\begin{tabular}{|c|c|c|c|}
\hline \multicolumn{4}{|c|}{ For Weight $\leq 70 \mathrm{Kg}$} \\
\hline & \multicolumn{2}{|c|}{ Efficacy } & \multirow{2}{*}{ P-Value } \\
\hline Group & Yes & No & \\
\hline A & $62(96.9 \%)$ & $2(3.1 \%)$ & \multirow{2}{*}{0.000} \\
\hline B & $35(50.7 \%)$ & $34(49.3 \%)$ & \\
\hline \multicolumn{4}{|c|}{ For Weight $>70 \mathrm{Kg}$} \\
\hline Group & Yes & No & \multirow{3}{*}{0.000} \\
\hline A & $34(82.9 \%)$ & $7(17.1 \%)$ & \\
\hline B & $12(33.3 \%)$ & $24(66.7 \%)$ & \\
\hline
\end{tabular}

Table-VIII. Stratification of efficacy with respect to weight in Group A and Group B

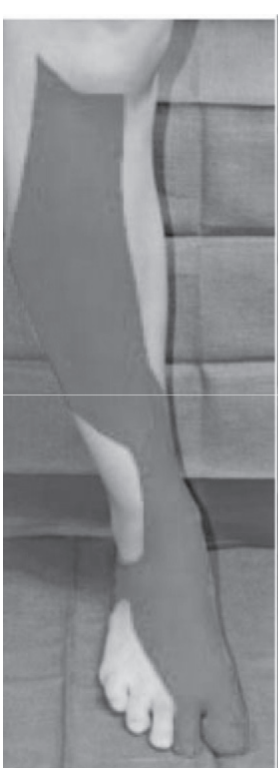

Figure-1

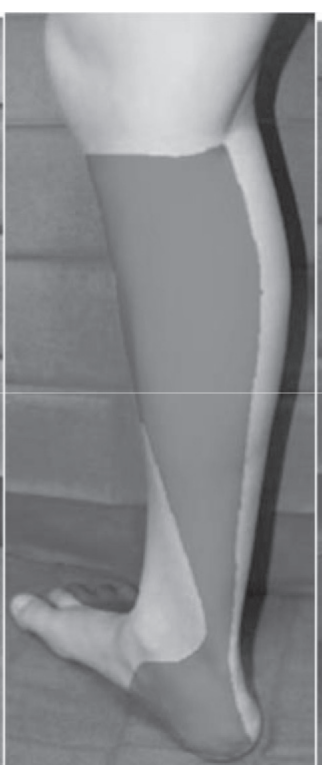

Figure-2

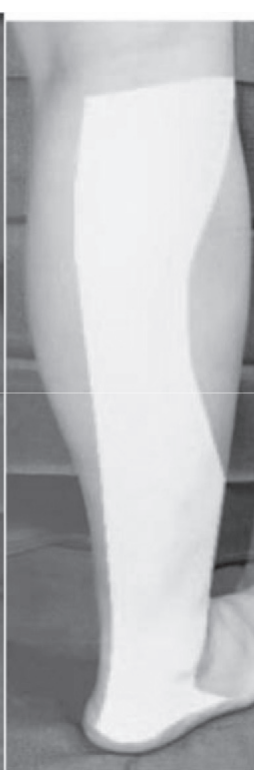

Figure-3
Figure-1. Anterior tibial artery angiosome territory (Dark Grey) Figure-2. The posterior tibial artery angiosome (Grey) Figure-3. The peroneal artery angiosome (White)

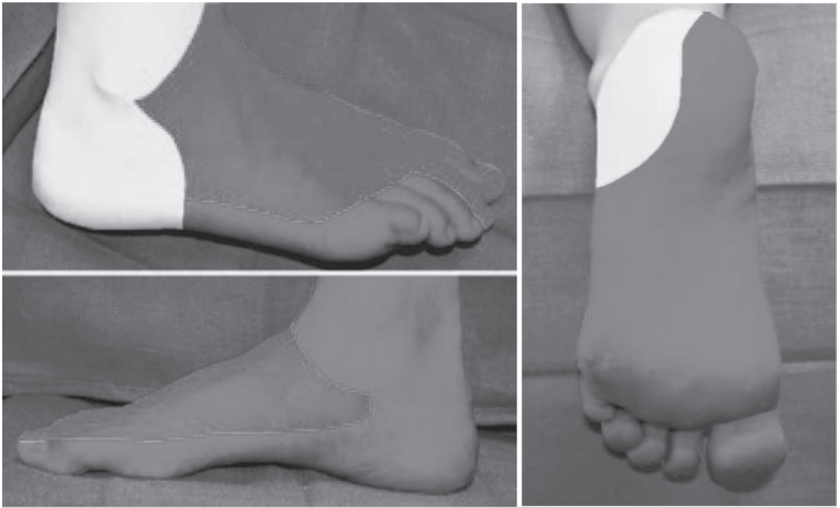

Figure-4. Angiosome of the foot and ankle.

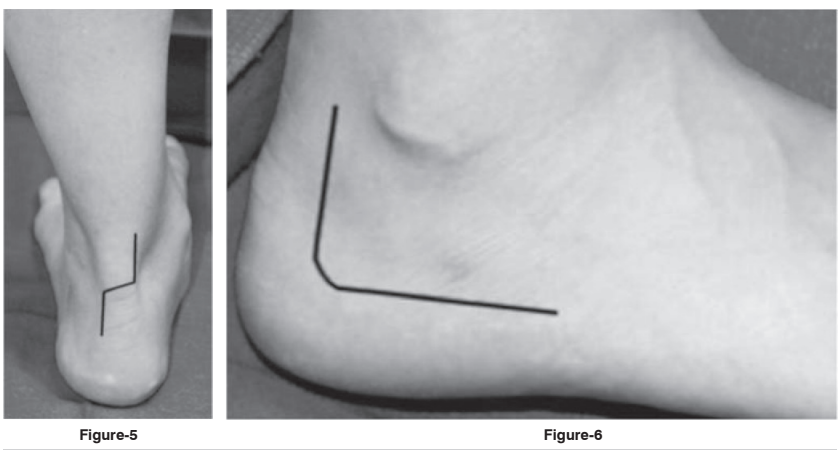

Figure5. Achilles tendon. A medial to lateral S-shaped incision. Figure 6. Lateral calcaneus.

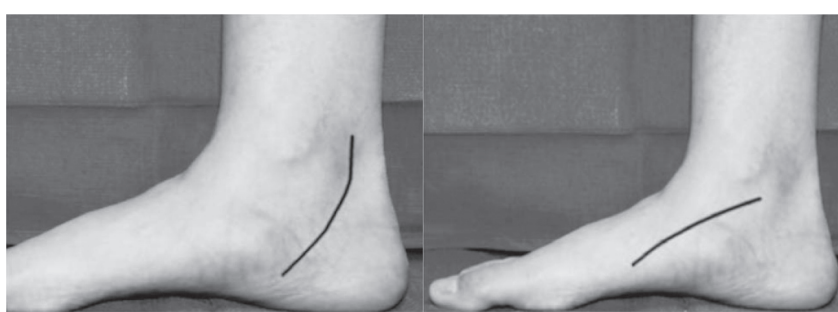

Figure-7. Medial calcaneus. Figure-8. Medial arch.

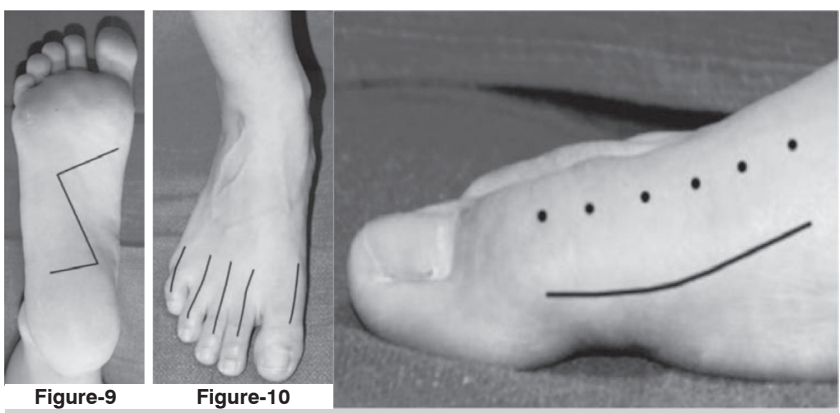

Figure-9. Plantar heel and midfoot. Curved or Z shaped incision.

Figure-10. Dorsal and plantar fore foot.

Figure-11. First metatarsophalangeal joint. 


\section{DISCUSSION}

It is important to know the vascular anatomy while placing incisions for diabetic foot ulcers. Incisions should not be place over the arteries. Angiosomes based incisions and good debridement can enhance the wound healing. ${ }^{13}$

4 important factors should be considered when placing an incision for DFU.

First, the incision must provide adequate exposure. Second, there must be adequate blood supply on either side of the incision for good healing. Third, the incision should spare the nerves. Fourth, the incision should not be placed perpendicular to a joint. ${ }^{13}$

Statistical analysis of our study shows that age wise both groups shows significant difference in efficacy of angiosome based incision group A $(p=0.000)$ as compared to group $B$. This shows that age has no limitation but it the incision which makes the difference. Efficacy of wound healing was better in group A then group B according to same age group.

Our study results shows that gender wise both groups shows significant difference in efficacy of angiosome based incision group $A(p=0.000)$ as compared to group $B$. This shows that gender has no limitation but it the incision which makes the difference. Gender wise efficacy of wound healing was better in group $A$ then group $B$. Statistically duration of diabetes either less than 10 years or more than 10 years has no effect on wound healing. It is angiosome based incision (Group A) which makes the difference $(P=0.000)$ then group $B$. It means efficacy of wound healing is batter in group $A$ then in group $B$.

Duration of diabetic foot ulcer dose effect on the wound healing. If duration of foot ulcer is less than 5 months, wound healing is batter in patients in which incisions were based on angiosome model (group A) as compared aggressive debridement (group B). But if the duration of diabetic foot ulcer is more than 5 months, statistically there is no difference in the wound healing in both the groups (Table-VI). Stratification of efficacy with respect to size of diabetic foot ulcer shows that if ulcer size is $4-6 \mathrm{~cm}^{2}$ there is no significant difference in wound ulcer healing in both the groups. But there is significant difference $(P=0.002)$ if ulcer size is more than $6 \mathrm{~cm}^{2}$ in both the groups. This shows that there is better wound healing in angiosome based incision as compared to aggressive debridement when diabetic foot ulcer is more than $6 \mathrm{~cm}^{2}$. This is the basic reason for the better wound healing when incisions were given according to angiosome model as shown in Table-VII.

Statistically weight of the patient has no effect on wound healing either weight is less than $70 \mathrm{Kg}$ or more than $70 \mathrm{Kg}$. It is angiosome based incision (Group A) which makes the difference $(P=0.000)$ then group $B$. It means efficacy of wound healing is batter in group $A$ then in group $B$ as shown in Table-VIII.

Diabetic Foot Ulcer treatment is multi-disciplinary approach, including serial debridement, diabetic control, treatment of sepsis and risk factors must also be employed when treating patients with DM.

\section{CONCLUSION}

Angiosome based incisions in the treatment of diabetic foot ulcer have shown outstanding outcomes with respect to wound healing compared with aggressive debridement.

\section{Copyright $@ 12$ Oct, 2019.}

\section{REFERENCES}

1. Shahbazian H, Yazdanpanah L, Latifi SM. Risk assessment of patients with diabetes for foot ulcers according to risk classification consensus of international working group on diabetic foot (IWGDF). Pak J Med Sci. 2013; 29:730-4.

2. Ramachandran A, Snehalatha C, Shetty AS, Nanditha A. Trends in prevalence of diabetes in Asian countries. World J Diabetes. 2012; 3:110-7.

3. Whiting DR, Guariguata L, Weil C, Shaw J. IDF diabetes atlas: Global estimates of the prevalence of diabetes for 2011 and 2030. Diabetes Res Clin Pract. 2011; 94:311-21. 
4. Aalaa M, Malazy OT, Sanjari M, Peimani M, MohajeriTehrani M. Nurses' role in diabetic foot prevention and care; A review. J Diabetes Metab Disord. 2012; $11: 24$.

5. Alavi A, Sibbald RG, Mayer D, Goodman L, Botros M, Armstrong DG, et al. Diabetic foot ulcers: part II. Management. J Am Acad Dermatol. 2014; 70:21.e12124.

6. Leone S, Pascale R, Vitale M, Esposito S. Epidemiology of diabetic foot. Infez Med. 2012; 20:8-13.

7. Bakri FG, Allan AH, Khader YS, Younes NA, Ajlouni KM. Prevalence of diabetic foot ulcer and its associated risk factors among diabetic patients in Jordan. Jordan Med J. 2012; 46:118-25.

8. Tallis A, Motley TA, Wunderlich RP, Dickerson JE, Waycaster C, Slade HB. Clinical and economic assessment of diabetic foot ulcer debridement with collagenase: Results of a randomized controlled study. Clin Ther. 2013; 35:1805-20.
9. Enoch S, Harding K. Wound bed preparation: The science behind the removal of barrier to healing Wounds. 2003; 15:213-29.

10. Söderström $M$, Albäck A, Biancari $F$, Lappalainen $K$, Lepäntalo $M$, Venermo $M$. Angiosome-targeted infrapopliteal endovascular revascularization for treatment of diabetic foot ulcers. J Vasc Surg. 2013; $57(2): 427-35$.

11. Taylor Gl, Palmer JH. The vascular territories (angiosomes) of the body: Experimental study and clinical applications. Br J Plast Surg 1987; 40:113-41.

12. Taylor GI, Pan WR. Angiosomes of the leg: Anatomic study and clinical implications. Plast Reconstr Surg 1998; 102:599-616.

13. Jaclyn M. Schwartz, DPM. Incision planning and placement in the lower extremity: Considerations for Dermal, Soft Tissue Angiosomes. Chapter 35 page 179- 184.

\begin{tabular}{|c|c|c|c|}
\hline \multicolumn{4}{|c|}{ AUTHORSHIP AND CONTRIBUTION DECLARATION } \\
\hline Sr. \# & Author(s) Full Name & Contribution to the paper & Author(s) Signature \\
\hline $\begin{array}{l}2 \\
3\end{array}$ & $\begin{array}{l}\text { Naveed Akhtar } \\
\text { Muhammad Ilyas Anjum } \\
\text { Shafiq Ullah }\end{array}$ & $\begin{array}{l}\text { Main author, surgeon and } \\
\text { perform the procedure. } \\
\text { Surgeon and perform the } \\
\text { procedure. } \\
\text { Collect the data. }\end{array}$ & \\
\hline 4 & Shahid Mansoor Nizami & Collect the data. & \\
\hline 5 & Uzma Rasheed & Analysis of data. & \\
\hline 6 & Anas Rabbani & Review of literature. & \\
\hline
\end{tabular}

